\title{
Wpływ pracy w czasie pandemii COVID-19 na stres personelu pielęgniarskiego
}

\author{
Impact of working during the COVID-19 pandemic \\ on nursing staff stress levels
}

LECH GRZELAK ${ }^{1,2}$, PIOTR SZWARC ${ }^{2}$

1 Państwowa Uczelnia Zawodowa we Włocławku

2 Specjalistyczny Szpital Miejski im. M. Kopernika w Toruniu

http://dx.doi.org/10.21784/IwP.2021.001

\section{Streszczenie}

Wstęp. Obciążenie stresem należy do poważnych zagrożeń zawodowych w pielęgniarstwie. Pandemia COVID-19 dodatkowo postawiła wiele nowych wyzwań przed personelem medycznym, co może powodować większe obciążenia psychiczne.

Cel. Celem badań była ocena wpływu pandemii COVID-19, na stres personelu pielęgniarskiego, niepracującego $\mathrm{w}$ bezpośrednim kontakcie z zakażonymi.

Materiały i metody. Badaniem objęto grupę 65 osób z personelu pielęgniarskiego, pracującego w siedmiu oddziałach szpitalnych. Wiek badanych mieścił się w zakresie 20-65 lat. W badaniach wykorzystano ankietę opracowaną na użytek badania oraz jedno standardowe narzędzia pomiaru, tj. Skalę Odczuwanego Stresu (PSS-10).

Wyniki. Wybuch pandemii spowodował zmianę w odczuwaniu stresu u 98,5\% badanych. 89,2\% osób zauważyło u siebie nasilone objawy stresu. Stres potęgowały przede wszystkim zmiany na poziomie organizacji pracy oraz lęk przed zakażeniem i przeniesieniem wirusa z pracy na rodzinę. U 6,2\% badanych często pojawiały się myśli o rezygnacji lub zmianie pracy. Po roku pracy w pandemii, stres utrzymywał się na poziomie średnim i niskim.

Wnioski. Poziom odczuwania stresu, mierzonego rok po wybuchu pandemii, nie wskazuje na obciążenie nadmiernym stresem, a na fazę adaptacji w sytuacji 
kryzysowej. Skutki pracy w długotrwałym stresie mogą być widoczne dopiero w przyszłości. Wskazane jest dalsze monitorowanie stresu i objęcie personelu pielęgniarskiego wsparciem psychologicznym.

Słowa kluczowe: stres zawodowy, poziom stresu, pandemia COVID-19, personel pielęgniarski, szpital niezakaźny.

\section{Summary}

Introduction. Stress is one of the major occupational hazards in nursing profession. The COVID-19 pandemic has further challenged healthcare professionals, which can increase mental strain.

The aim. The purpose of the study was to assess the impact of the COVID-19 pandemic on stress levels of nursing staff not working in close proximity to the infected patients.

Materials and methods. The study involved a group of 65 people from nursing staff working in seven hospital wards. The respondents were aged between 20-65 years. For the purpose of the research, the author's own survey and one standard research tool were used, i.e. The Perceived Stress Scale (PSS-10).

Results. The outbreak of the pandemic resulted in a change in the perception of stress in $98.5 \%$ of respondents. $89.2 \%$ of people noticed more intense symptoms of stress. Stress was compounded, above all, by changes at the level of work organization as well as the fear of infection and the transmission of the virus from the work environment to family members. In $6.2 \%$ of respondents, thoughts about quitting or changing jobs were quite frequent. After one year of working in a pandemic, stress levels were moderate to low.

Conclusions. The level of stress, measured one year after the outbreak of the pandemic, does not indicate excessive stress, but the adaptation phase in a crisis situation. The effects of working under chronic stress may not be visible until the future. Further stress monitoring and providing nursing staff with psychological support is highly advisable.

Keywords: occupational stress, stress level, pandemic COVID-19, nursing staff, non-infectious hospital. 


\section{Wstęp}

Praca personelu pielęgniarskiego, w powszechnej opinii, uchodzi za zajęcie silnie obciążające fizycznie i psychiczne. To zawód, w którym bardzo ważną rolę odgrywa bliski kontakt interpersonalny oraz związany z nim proces zaangażowania i wymiany emocjonalnej. Zadania realizowane $\mathrm{w}$ trosce i w poczuciu odpowiedzialności za zdrowie i życie drugiego człowieka oraz zmianowy system pracy odciskają piętno zarówno na zdrowiu fizycznym, jak i psychicznym. Doświadczanie długotrwałego stresu, połączonego z brakiem umiejętności radzenia sobie z nim, z czasem prowadzi do przeciążeń w funkcjonowaniu organizmu, a w konsekwencji często do wypalenia zawodowego. Z tego względu stres personelu pielęgniarskiego, w różnych jego aspektach, od wielu lat jest przedmiotem opracowań i badań naukowych.

W dobie trwającej pandemii, szukanie odpowiedzi na pytania, dotyczące stresu personelu pielęgniarskiego, pracującego od ponad roku w trudnych warunkach, jest jeszcze bardziej istotne. Pandemia COVID-19 nosi znamiona kryzysu katastroficznego, który powoduje oddziaływanie wielu stresorów jednocześnie. Niezwykle trudna sytuacja nasila doświadczanie strachu, lęku i depresji. Decyzje podejmowane na różnych szczeblach pod presją czasu, powodują destabilizację i niepewność. Z kolei częste doświadczanie śmierci, towarzyszące epidemiom, nasila ryzyko zaburzeń traumatycznych. Lu i wsp. oraz Ornell i wsp. w swych opracowaniach sygnalizują, że zmiany w sferze psychicznej nie dotyczą tylko pracowników służby zdrowia, pracujących w bezpośrednim kontakcie z zarażonymi wirusem SARS-CoV-2, ale także tych, którzy doświadczają zawodowych i organizacyjnych zmian z powodu epidemii [1]. Rodzą się więc pytania o sytuację zdrowotną personelu pielęgniarskiego, pracującego w polskim środowisku medycznym.

Cel

Celem pracy badawczej, była ocena wpływu pandemii COVID-19 na stan psychiczny personelu pielęgniarskiego, pracującego w szpitalu niezakaźnym, czyli poza tzw. „pierwszą linią frontu”. Badania dają 
wgląd w to, czy pielęgniarki w Polsce radzą sobie z nowym wyzwaniem, czy po roku czasu od wybuchu epidemii pracują na skraju wyczerpania emocjonalnego oraz czy należałoby je objąć dodatkowym wsparciem terapeutycznym. Szpital, w którym przeprowadzano badania, zarówno wiosną i jesienią 2020 r., stał się dużym ogniskiem koronawirusa, powodując zakażenia wśród wielu pracowników. Personel pielęgniarski doświadczył więc bezpośredniego kontaktu z zagrożeniami, jakie niesie ze sobą pandemia.

\section{Materiał i metody}

Badania przeprowadzono z wykorzystaniem dwóch metod badawczych - sondażu diagnostycznego i szacowania. Skorzystano przy tym z techniki ankietowania i pomiaru. Za narzędzia badawcze posłużył kwestionariusz ankiety własnej, stworzony na potrzeby badania oraz Skala PSS-10 - Skala Odczuwanego Stresu, należąca do zbioru „Narzędzia Pomiaru Stresu i Radzenia Sobie ze Stresem” Zygfryda Juczyńskiego i Niny Ogińskiej-Bulik.

Badania zostały przeprowadzone w marcu 2021 r. Objęto nimi personel pielęgniarski Specjalistycznego Szpitala Miejskiego im. M. Kopernika w Toruniu z siedmiu oddziałów. Udział w badaniu miał charakter anonimowy i dobrowolny. Przed przystąpieniem do badań uzyskano pisemną zgodę Komisji Bioetycznej nr INoZ.003.01.2021 oraz zgodę Dyrektora Szpitala nr N/Znak:SMM/Z-caDyr.DP/3/2021.

Badanie przeprowadzono z uwzględnieniem szpitalnych procedur epidemiologicznych. Z dostarczonych na oddziały ankiet, otrzymano 70 kwestionariuszy zwrotnych. W procesie badawczym, na podstawie poprawności wypełnionych kwestionariuszy i arkuszy skali, do badań statystycznych zakwalifikowano grupę 65 osób, pracujących łącznie w siedmiu oddziałach.

Materiał badawczy wprowadzono do specjalnie opracowanej na potrzebę badań bazy danych programu Excel. Wszystkie obliczenia wykonano za pomocą pakietu statystycznego SPSS Statistics 21,0. W celu zbadania zależności statystycznej pomiędzy analizowanymi cechami 
posłużono się testem istotności chi-kwadrat. Uzyskane wyniki badań poddano analizie statystycznej testem $\chi^{2}$ dla prób niezależnych. Przyjęto 5\% ryzyka błędu wnioskowania. Wartość prawdopodobieństwa $\mathrm{p}<0,05$ uznano za statystycznie istotną.

\section{Wyniki}

Badaną grupę w większości, bo aż 96,9\%, stanowiły kobiety, pozostałe $3,1 \%$ to mężczyźni. Największą grupę badanych tworzyli respondenci w wieku 41-50 lat (33,8\%) oraz respondenci w wieku powyżej 51 lat $(32,3 \%)$, co oznacza, że $2 / 3(66,1 \%)$ całej grupy miała ukończone 40 lat. W przedziale wiekowym 20-30 lat mieściło się 23,1\% respondentów. Najmniejszą część 10,8\% stanowili badani pomiędzy 31 a 40 rokiem życia.

Najwięcej respondentów miało wykształcenie średnie i stanowili $38,5 \%$ całej grupy. Niewiele mniej miało ukończony licencjat z pielęgniarstwa (32,3\%). 30\% grupy respondentów zdobyło tytuł magistra pielęgniarstwa.

Największa grupa badanych 27,7\% pracowała w zawodzie powyżej 30 lat. Staż zawodowy pomiędzy 26 a 30 lat posiada $20 \%$ respondentów, natomiast $18,5 \%$ badanych deklarowała go w przedziale między 1 a 5 lat. Liczba osób w pozostałych grupach rozkładała się następująco: 10,8\% z doświadczeniem 21-25 lat, 7,7\% z doświadczeniem 16-20 lat, 6,2\% z doświadczeniem 6-10 lat. Najmniejsze grupy po 4,6\% tworzyły osoby mające za sobą 11-15 lat i te które dopiero co zaczęły pracę w zawodzie.

Cztery grupy badanych, stanowiące $15,4 \%$ każda, pochodziły z oddziałów chirurgii, OIT, neurochirurgii i neurologii. Dwie grupy, stanowiące 13,8\% każda, były zatrudnione w oddziale urazowo-ortopedycznym i urologicznym. Najmniejszą grupę niewiele ponad 10,8\% stanowił personel oddziału chorób wewnętrznych.

Korzystając z ankiety własnej, zapytano respondentów o zamianę w odczuwaniu stresu przed pandemią COVID-19 i zaraz po jej wybuchu, objawy stresu, które się nasiliły w obliczu zagrożenia. Respondenci wskazali też czynniki wysoce stresogenne w miejscu pracy, lęki i obawy, 
z jakimi się mierzyli oraz sposobami, jakimi łagodzili nadmierny stres. Badani wypowiedzieli się, czy praca w czasie pandemii powodowała myśli o rezygnacji z pracy oraz czy personelowi pielęgniarskiemu należałoby zapewnić większe wsparcie psychologiczne.

Analiza statystyczna, badająca wpływ pandemii COVID-19 na zmianę odczuwania stresu związanego z pracą, wykazała istotną zależność między jej wybuchem a stresem. Przed pandemią 58,5\% respondentów czasami odczuwało stres związany z przyjściem do pracy, 24,6\% prawie nigdy go nie odczuwało, a $16,9 \%$ w ogóle. Wraz z początkiem pandemii, stres przed rozpoczęciem obowiązków zawodowych 9,2\% respondentów odczuwało zawsze, 15,4\% - prawie zawsze, 60\% - czasami, 13,8\% - prawie nigdy. Tylko 1 osoba (1,5\%,) nie czuła różnicy. Oznacza to zmianę w odczuwaniu stresu związanego z pracą u 98,5\%.

Większe obciążenie psychiczne $\mathrm{w}$ pracy nasiliło $\mathrm{u}$ respondentów doświadczanie objawów stresu. Najczęściej zgłaszanymi objawami stresu były nerwowość i rozdrażnienie - u 55,4\% badanych oraz złe samopoczucie - u 29,2\% badanych. W mniejszym nasileniu występowały ból brzucha i ból głowy - u 13,8\% badanych, huśtawki nastrojów - u 12,3\%, problemy ze snem - u 10,8\%, problemy z koncentracją - u 9,2\%.

Badani wymienili wiele wysoce stresogennych czynników w miejscu pracy. Dla ponad połowy ankietowanych $(56,9 \%)$ czynnikiem nasilającym odczuwanie stresu była zmiana organizacji pracy w szpitalu, dla 43,1\% - konieczność stosowania dodatkowych środków ochrony osobistej, a dla 36,9\% ( $\mathrm{n}=24)$ - ekspozycja na czynnik chorobotwórczy. 30,8\% badanych zwróciło uwagę na pogorszenie atmosfery współpracy w zespole, a 27,7\% - na nadmierne obciążenie pracą. Wśród innych często wskazywanych czynników należy: praca na innym oddziale $(23,1 \%)$, odpowiedzialność za zdrowie i życie innych $(21,5 \%)$, szybkie wdrażanie nowych procedur (20\%), nadgodziny $(16,9 \%)$ osób stresowały, niezadowoleniem pacjentów (15,4\%).

Respondenci wraz z nastaniem pandemii doświadczali różnych obaw, wpływających na obciążenie psychiczne i potęgujących stres. Prawie $65 \%$ ankietowanych obawiało się przeniesienia wirusa z miejsca pracy na naj- 
bliższych, a blisko połowa (49,2\%) bała się utraty bliskich jej osób. Blisko $30 \%$ badanych obawiało się zakażenia oraz utraty własnego zdrowia i życia. $27,7 \%$ respondentów stresowała możliwość przeniesieniu wirusa na pacjentów oraz utraty kontaktów społecznych przez pandemię.

Badani w chwilach odczuwania nadmiernego stresu spowodowanego pracą, próbowali łagodzić stres różnymi sposobami. Przeszło połowa badanych $(55,4 \%)$ rozmawiała ze współpracownikami, prawie $1 / 3$ badanych (30,8\%) osób szukała oparcia u swoich najbliższych kontaktując się z nimi, 15,4\% wybierało rozmowę z przełożonym, a 3,1\% szukało pomocy u specjalisty. $23,1 \%$ badanych nie robiło nic z nadmiernym stresem, a 4,6\% za najlepsze rozwiązanie uważało urlop. Analiza statystyczna wpływu wieku, wykształcenia, doświadczenia zawodowego i miejsca zatrudnienia na wybierany sposób radzenia sobie przez badanych z nadmiernym stresem w pracy, nie wykazała zależności między nimi.

Wśród badanych znalazły się osoby, u których praca w stresujących warunkach pandemii, może wpłynąć na zmianę lub porzuceniu zawodu. Myśl ta często pojawiała się u 6,2\% respondentów. 13,8\% myślała o tym czasami, a 16,9\% bardzo rzadko. 63,1\% badanych w ogóle nie myślała o tym. W grupie wiekowej pomiędzy 31 a 40 r. ż., myśli o zmianie zawodu lub o rezygnacji z pracy pojawiały się znacznie częściej (u około 70\% osób) niż w pozostałych grupach wiekowych. Z kolei wśród najstarszej grupy wiekowej powyżej 51 r. ż., najmniej respondentów rozważała w swojej głowie taką możliwość (około 29\% osób).

W opinii większej części grupy objętej badaniem, obciążenie długotrwałym stresem, może zwiększyć zapotrzebowanie na wsparcie psychologiczne dla personelu pielęgniarskiego. 58,5\% respondentów dostrzegło potrzebę zwiększenia wsparcia specjalistycznego dla środowisk pielęgniarskich, pracujących $\mathrm{w}$ warunkach pandemii. Tylko $7,7 \%$ badanych w ogóle nie widzi takiej potrzeby.

Wykorzystując arkusz Skali PSS-10, oszacowano poziom natężenia stresu personelu pielęgniarskiego, pracującego $\mathrm{w}$ warunkach pandemicznych po upływie roku od wybuchu pandemii COVID-19. Ankietowani odpowiadając na pytania dotyczące różnych subiektywnych odczuć 
związanych ze zdarzeniami osobistymi, z problemami, z zachowaniami i ze sposobami radzenia sobie z nimi, oznaczali odpowiedzi posługując się skala cyfrową 0-4 (oznaczającą: nigdy, prawie nigdy, czasem, dość często, bardzo często). Wynik poddano analizie i skategoryzowano poziom natężenia stresu zgodnie z normami kwestionariusza. Oszacowano poziom natężenia odczuwanego stresu u badanych, mieszczący się w granicach między 3 a 6 stenem (patrz tabela 1 i rysunek 1), z czego $55,4 \%$ badanych osiągnęła wartość na poziomie 5 stena, a 38,5\% na po-

Tabela 1. Wyniki Skali Odczuwania Stresu (PSS-10) - steny.

\begin{tabular}{|c|r|c|}
\hline \multirow{2}{*}{ Wyniki stenowe } & \multicolumn{2}{|c|}{ Badani } \\
\cline { 2 - 3 } & $\mathbf{n}$ & \% \\
\hline 3,00 & 2 & 3,1 \\
\hline 4,00 & 25 & 38,5 \\
\hline 5,00 & 36 & 55,4 \\
\hline 6,00 & 2 & 3,1 \\
\hline Ogółem & $\mathbf{6 5}$ & $\mathbf{1 0 0 , 0}$ \\
\hline
\end{tabular}

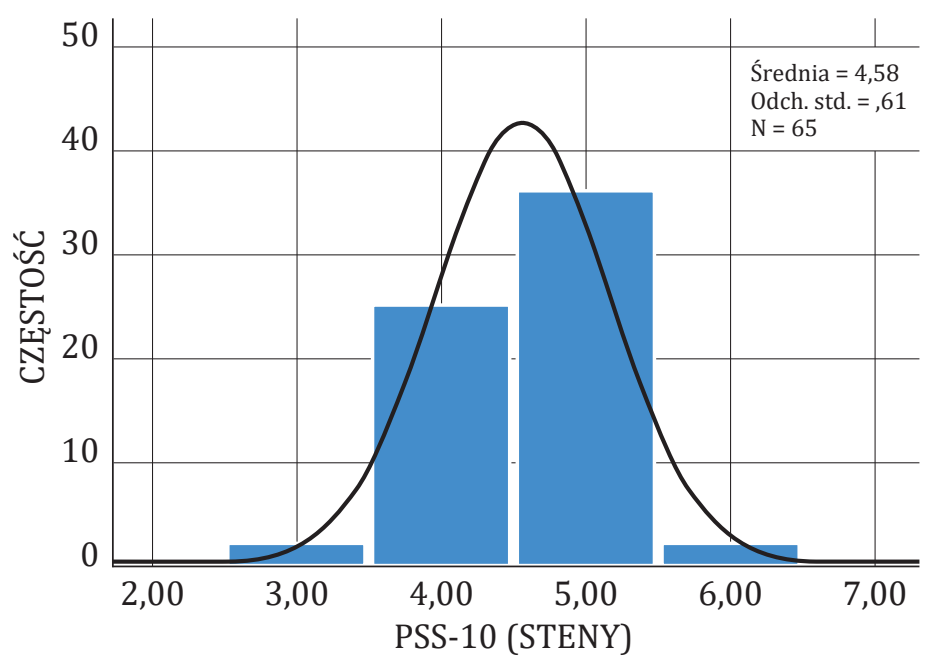

Ryc. 1. Wyniki Skali Odczuwania Stresu (PSS-10) - histogram. 
ziomie 4 stena. Zestawienie uzyskanych wyników z zakresami wartości stenów (patrz tabela 2), wskazuje na niski i przeciętny poziomu odczu-

Tabela 2. Poziom natężenia stresu oszacowanie na podstawie skali PSS-10.

\begin{tabular}{|c|c|c|c|c|}
\hline \multicolumn{2}{|c|}{ Steny } & \multicolumn{2}{c|}{ Poziom } & \multicolumn{2}{c|}{ Badani } \\
\cline { 1 - 3 } Zakres & $\begin{array}{c}\text { Uzyskany } \\
\text { wynik }\end{array}$ & odczuwanego stresu & n & \% \\
\hline $1-4$ & 3,4 & wynik niski & 27 & 41,5 \\
\hline $5-6$ & 5,6 & wynik przeciętny & 38 & 58,5 \\
\hline $7-10$ & - & wynik wysoki & - & - \\
\hline \multicolumn{2}{|c|}{ Ogółem } & $\mathbf{6 5}$ & $\mathbf{1 0 0}$ \\
\hline
\end{tabular}

wania stresu przez badanych, przy czym 58,5\% osób uzyskało wynik na poziomie średnim, a 41,5\% osób - na poziomie niskim. Przeprowadzona następnie analiza statystyczna wykazała, że poziom odczuwanego stresu nie zależy od wieku badanych, ich wykształcenia, doświadczenia zawodowego i miejsca zatrudnienia.

\section{Dyskusja}

Analizując wyniki badań trudno omówić je w odniesieniu do podobnych badań na gruncie polskim czy europejskim. Liczba opublikowanych prac na temat wpływu pandemii COVID-19 na zdrowie psychiczne polskiej populacji, w tym personelu medycznego, jest jeszcze znikoma. Często polskie publikacje zbierają i analizują badania pochodzące głównie z Azji, prowadzone w czasie pandemii COVID-19 oraz wcześniejszej SARS czy MERS.

Wyniki badań dotyczące stresu, jakiego doświadczał personel pielęgniarski przed wybuchem pandemii i w czasie jej trwania, wskazuje na istotna zmianę, jaka nastąpiła w odczuwanych emocjach związanych z pracą. Nawet osoby dobrze radzące sobie ze stresem, deklarowały istotną zmianę w sferze emocjonalnej po wybuchu pandemii. Wyniki korelują ze wstępnym raportem Dragan i wsp., którzy badali zakres wpływu pandemii na obciążenie psychiczne Polaków trzy miesiące od 
jej wybuchu. Wg raportu dla 75\% badanych pandemia okazała się silnie działającym stresorem [2]. Na pogorszenie zdrowia medyków wskazuje z kolei raport z badania kondycji psychicznej personelu medycznego Buchlet i Kowalskiej-Bobko, w którym 38\% objętych badaniem pielęgniarek zgłosiło pogorszenie stanu emocjonalnego [3]. Grupa objęta badaniem, od wybuchu pandemii zauważyła u siebie nasilenie objawów wynikających z obciążenia stresem, takich jak: nerwowość i rozdrażnienie, złe samopoczucie, ból brzucha, bóle głowy, problemy z koncentracją. Dodatkowo badani doświadczali różnego rodzaju niepokoju, strachu i lęku, które odbierają poczucie bezpieczeństwa i zwiększają poziom stresu. Największą obawą było przeniesie wirusa z pracy do domu i stworzenie zagrożenia dla bliskich oraz zakażenie siebie i utrata własnego zdrowia i życia. Obok silnie obciążających odczuć, badani wskazali wiele czynników w swoim środowisku pracy, które uznali za wysoce stresogenne. Wśród najsilniej potęgujących stres czynników okazała się szybka zmiana organizacji pracy w szpitalu, a zaraz po niej stosowanie środków ochrony osobistej. Znaczny odsetek wskazywał także na pogorszenie atmosfery współpracy, nadmierne obciążenie pracą, przenoszenie na inne oddziały, szybkie wdrażanie procedur. Pandemia i wynikające z niej nagłe zmiany, postawiły przed pracownikami szpitala nowe wyzwania i wysokie wymagania, a przy tym brak możliwości wyboru i poczucie braku wpływu na sytuację, co wg teorii „wymagania - kontrola" Karaski, stanowi najsilniej stresogenne okoliczności w miejscu pracy [4].

Ważną częścią badań było sprawdzenie poziomu natężenia stresu personelu pielęgniarskiego, mierzonego po upływie roku od wybuchu pandemii. Chociaż badani zgłaszali zmiany w odczuwaniu stresu oraz nasilenie jego objawów po wybuchu epidemii, skala pomiarowa wykazała odczuwanie stresu na poziomie średnim u $58,5 \%$ osób i na poziomie niskim u 41,5\%. Nie znaleziono istotnego związku pomiędzy poziomem odczuwanego stresu a takimi zmiennymi, jak wiek, wykształcenie, doświadczenie zawodowe czy miejsce pracy. Wskazanym byłoby tu porównanie z poziomem stresu personelu pielęgniarskiego szpitala niezakaźnego na 
początku pandemii, co dałoby wgląd w to, na ile odczuwanie stresu uległo zmianie. Badań takich brak. Początki pandemii były trudne dla wszystkich polskich szpitali, a wielu pracującym medykom towarzyszyły często skrajnie negatywne emocje. Po upływie roku wszyscy nauczyli się żyć i pracować $w$ warunkach pandemii, a na horyzoncie pojawiały się nadzieje, związane ze stworzeniem szczepionki przeciwko COVID-19.

Odczuwanie niskiego poziomu stresu nie prowadzi zwykle do przeciążeń w sferze psychicznej, a oddziałuje bardziej na jakość i wydajność w pracy. Nieco inna reakcja organizmu następuje pod wpływem średniego poziomu stresu, zwłaszcza gdy jest on regularnym doświadczeniem. Odczuwanie ciągłego pobudzenia pod wpływem stresu, może doprowadzić do negatywnych skutków w funkcjonowaniu zawodowym jednostki. Odwołując się do teorii oddziaływania stresu wg Selyego, nasuwa się wniosek, że personel pielęgniarski jest w fazie adaptacyjnej (mobilizacji zasobów, odporności). Odczuwa pobudzenie stresowe, ale poziom stresu nie dochodzi do wysokich wartości. Selye wykazuje też, że gdy sytuacja stresogenna wydłuża się w czasie (stres staje się przewlekły), a siła oddziaływania stresu nie jest zbyt duża, drastycznie maleją zasoby zaradcze organizmu, co prowadzi do objawów psychicznych i/lub somatycznych [1]. W odpowiedzi na optymalne wykorzystanie zasobów, zmienia się oddziaływanie stresu i zwiększa jego nasilenie, powodując dezintegrację psychiczną, wyczerpanie, wyniszczenie. Przedmiotem badań nie była ocena zasobów, jakimi dysponuje personel pielęgniarski, dlatego nie jest możliwe wskazanie rodzaju i stopnia ich wykorzystania. Jednak poziom odczuwanego stresu przez badany personel, nasuwa wniosek, że nie zostały przekroczone wartości optymalnej odporności na stres, a badani dalej dysponują zasobami, potrzebnymi do radzenia sobie w stresogennych warunkach pracy i potrafią z nich odpowiednio korzystać. Należy przy tym pamiętać, że jeśli pandemia będzie nadal trwać, mechanizmy adaptacyjne, na skutek działania długotrwałego stresu, mogą ulec wyczerpaniu. Może to doprowadzić u niektórych do zaburzeń adaptacyjnych albo rozwinięcia zaburzeń po wtórnym stresie traumatycznym [5]. 
Dyskutując o poziomie stresu grupy objętej badaniem, nie można pominąć faktu wsparcia społecznego, z którego korzysta ona w momentach odczuwania silnego stresu. Najczęściej wybieranym sposobem radzenia sobie z nadmiernym stresem była rozmowa ze współpracownikami, szukanie wsparcia w rodzinie i rozmowa z przełożonym. Ogińska-Bulik (2020), prowadząca badania nad negatywnymi i pozytywnymi skutkami wtórnej ekspozycji na traumę personelu medycznego, który pracował bezpośrednio z osobami cierpiącymi lub poszkodowanymi (nie w wyniku pandemii COVID-19), wykazała istotne powiązanie między rolą wsparcia społecznego, a łagodzeniem skutków traumatyzacji wtórnej. Badanie przeprowadzono w grupie 165 osób, z czego 30\% stanowił personel pielęgniarski, z którego 91\% to kobiety. Dla badanych wsparcie pochodzące od rodziny spełniało rolę ochronną przed rozwinięciem się objawów wtórnego stresu. Wsparcie pozyskiwane ze środowiska pracy, pochodzące głównie od współpracowników, sprzyjało wtórnym zmianom potraumatycznym, ale pozytywnym [6]. Z kolei Xiao i wsp. (2020) przeprowadzili badania wpływu wsparcia społecznego na personel medyczny, leczący pacjentów chorych na COVID-19. Badanie wykazało, że uzyskanie wsparcia społecznego zmniejsza poziom lęku i stresu, zwiększa skuteczność i pozytywnie wpływa na samopoczucie [7].

Piętno pandemii coraz częściej wywołuje pytania o przyszłość polskiego pielęgniarstwa. Prognozuje się, że silnie oddziałujące negatywne doświadczenia związane z pandemią, powiększą problem niedoszacowania kadr pielęgniarskich. Wśród personelu pielęgniarskiego, objętego badaniem, częste myśli o zmianie lub porzuceniu zawodu towarzyszyły grupie 6,2\%. Wspomniany już raport Buchlet i Kowalskiej-Bobko, mówi o grupie 6,3\% pielęgniarek, myślących o odejściu z zawodu i grupie 3,8\% myślących o migracji [3]. Szacując, że obecna aktywna grupa zawodowa liczy 230433 pielęgniarek, zawieszenie aktywności zawodowej 6\% tej grupy, oznaczałoby odpływ 13826 pielęgniarek z polskiego systemy opieki zdrowotnej w wyniku wpływu pandemii. To pokazuje jak ważne jest wsparcie dla tych, których praca w pandemii silnie ob- 
ciążyła psychicznie oraz promowanie zawodu przez podnoszenie jego prestiżu w Polsce.

Najbliższa przyszłość polskiego pielęgniarstwa, rodzi pytania o wpływ pandemii na zdrowie psychiczne pielęgniarek oraz o działania mające na celu złagodzenie negatywnych skutków jej oddziaływania. Grupa blisko 60\% badanych była przekonana o konieczności zwiększenia pomocy psychologicznej na rzecz personelu pielęgniarskiego, jako grupy zawodowej. Na potrzebę wsparcia pod tym względem wskazują też dostępne badania. Li i wsp. (2020) prowadzili badania pod kątem występowania wśród personelu medycznego zastępczej traumatyzacji. Rekomendują oni objęcie wsparciem psychologicznym, nie tylko pracowników medycznych z pierwszej linii walki, ale także tych opiekujących się pacjentami niezakażonymi [8].

\section{Wnioski}

Wraz z wybuchem pandemii COVID-19, można zaobserwować zmianę odczuwania stresu przez personel pielęgniarski, w porównaniu do okresu sprzed pandemii, o czym świadczy nasilenie się objawów stresu.

Czynniki najsilniej obciążające psychicznie personel pielęgniarskiego w czasie pandemii na poziomie odczuć to: obawa przed przeniesieniem wirusa z miejsca pracy na bliskich oraz zagrożenie życia i zdrowia własnego i bliskich; na poziomie organizacji to: szybko wprowadzane zmiany organizacyjne oraz ciągła praca w podwyższonym reżimie sanitarnym.

Personel pielęgniarski w chwilach narastającego stresu korzysta przede wszystkim ze wsparcie współpracowników i rodziny.

Pomimo pracy przez ostatni rok w warunkach podwyższonego stresu, personel pielęgniarski, niepracujący w bezpośrednim kontakcie z zakażonymi, odczuwa stres na poziomie niskim i średnim. Nie jest to poziom skrajnego obciążenia stresem i wskazuje bardziej na fazę adaptacji.

Praca w długotrwałym stresie, spowodowanym pandemią, wywołuje myśli o rezygnacji lub zmianie zawodu, co może spowodować, że część personelu pielegniarskiego zrezygnuje z zawodu. 
Obciążenie długotrwałym stresem może zwiększyć zapotrzebowanie na pomoc psychologiczną dla personelu pielęgniarskiego.

\section{Zalecenia dla praktyki pielęgniarskiej}

Długotrwały stres, nawet jeżeli nie osiąga wysokich wartości, jak w przypadku objętego badaniem personelu, może stanowić zagrożenie w sferze psychofizycznej. Dlatego istotne znaczenie ma dalsze monitorowanie poziomu stresu oraz podnoszenie świadomości stresu zawodowego i środków zaradczych. Wskazane byłoby objęciem personelu medycznego oddziaływaniami, które rozwiną przede wszystkim umiejętność radzenia sobie ze stresem o charakterze traumatycznym. Od początku pandemii $\mathrm{w}$ wielu strukturach pielęgniarskich uruchomiono poradnictwo i pomoc psychologiczną, w celu objęcia opieką koleżanek i kolegów, którzy nie radzą sobie ze stresem, strachem i lękiem wywołanym pandemią. Wskazane byłoby większe promowanie tego typu pomocy.

\section{Bibliografia/ Bibliography:}

1. Talarowska M.,ChodkiewiczJ., Nawrocka N.Zdrowie psychiczne a epidemia SARS-COV-2 - badania polskie. https://www.researchgate.net/publication/ 342845107_Mental_health_and_the_epidemic_SARS-COV-2_-_risk_ factors_Polish_research_Zdrowie_psychiczne_a_epidemia_SARS-COV-2_-badania_polskie [data dostępu: 29.05.2021 r.]

2. Dragan M. Zdrowie psychiczne w czasie pandemii Covid-19. Wydział Psychologii Uniwersytetu Warszawskiego. http://psych.uw.edu. pl/2020/05/04/zdrowie-psychiczne-w-czasie-pandemii-covid-19-raport-wstepny-z-badania-naukowego-kierowanego-przez-dr-hab-malgorzate-dragan [data dostępu: 16.05.2021 r.]

3. Buchelt B., Kowalska-Bobko I. Zarządzanie zasobami ludzkimi w systemie ochrony zdrowia w czasach pandemii. Małopolska Szkoła Administracji Publicznej Uniwersytetu Ekonomicznego. Kraków 2020. https:// politykipubliczne.pl/wp-content/ uploads/2020/10/09-Ochrona-zdrowia_16.09.2020-last.pdf [data dostępu: $16.05 .2021 \mathrm{r}$.] 
4. Molek-Winiarska D. Interwencje antystresowe w organizacji. Modele. Zarządzanie. Efektywność. Wydawnictwo Uniwersytetu Ekonomicznego. Wrocław 2020.

5. Wierzbiński P. Stres $\mathrm{w}$ dobie pandemii COVID-19 - subiektywna perspektywa psychiatry. Psychiatria i Psychologia Kliniczna 2020, 20 (2), p. 98-101. http://www.psychiatria.com.pl/ index.php/wydawnictwa/ 2020-vol-20-no-2/stres-w-dobie-pandemii-covid-19-subiektywna-perspektywa-psychiatry?aid=933 [data dostępu: 29.05.2021 r.]

6. Ogińska- Bulik N. Negatywne i pozytywne skutki wtórnej ekspozycji na traumę wśród personelu medycznego - rola wsparcia społecznego. https://journals.viamedica.pl/ psychiatria/ article/view/72596 [data dostępu: 29.06.2021 r.]

7. Szambor T., Masiak J., Urbańska A. Związek pomiędzy sprawowaniem opieki medycznej nad osobami z chorobą COVID-19 a zdrowiem psychicznym pracowników ochrony zdrowia. Polish Journal of Public Health 2019;129(4): 145-147. http://search.ebscohost.com > login > sUUI [data dostępu: 30.05.2021 r.]

8. Gawrych M. Zdrowie psychiczne pracowników medycznych w czasie pandemii COVID-19 - przegląd literatury. Psychiatria Polska Nr 215: 1-8, luty 2021. http://www.psychiatriapolska.pl/uploads/onlinefirst/Gawrych_ PsychiatrPolOnlineFirstNr213.pdf [data dostępu: 30.05.2021 r.] 